\title{
Article
}

\section{Measurement of Food Safety Culture using Survey and Maturity Profiling Tools}

Jespersen, Lone, Griffiths, Mansel, Maclaurin, Tanya, Chapman, Ben and Wallace, Carol A.

Available at http://clok.uclan.ac.uk/13753/

Jespersen, Lone, Griffiths, Mansel, Maclaurin, Tanya, Chapman, Ben and Wallace, Carol A. ORCID: 0000-0002-1402-2134 (2016) Measurement of Food Safety Culture using Survey and Maturity Profiling Tools. Food Control, 66 . pp. 174-182. ISSN 09567135

It is advisable to refer to the publisher's version if you intend to cite from the work. http://dx.doi.org/10.1016/j.foodcont.2016.01.030

For more information about UCLan's research in this area go to http://www.uclan.ac.uk/researchgroups/ and search for <name of research Group>.

For information about Research generally at UCLan please go to http://www.uclan.ac.uk/research/

All outputs in CLoK are protected by Intellectual Property Rights law, including Copyright law. Copyright, IPR and Moral Rights for the works on this site are retained by the individual authors and/or other copyright owners. Terms and conditions for use of this material are defined in the policies page. 


\section{Accepted Manuscript}

Measurement of Food Safety Culture using Survey and Maturity Profiling Tools

Lone Jespersen, Dr. Mansel Griffiths, Dr. Tanya Maclaurin, Dr. Ben Chapman, Carol A. Wallace, Prof.

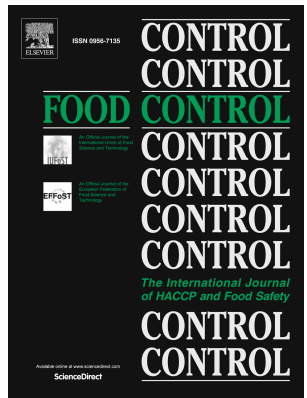

PII: S0956-7135(16)30031-7

DOI: $\quad$ 10.1016/j.foodcont.2016.01.030

Reference: $\quad$ JFCO 4840

To appear in: Food Control

Received Date: 21 June 2015

Revised Date: 21 January 2016

Accepted Date: 24 January 2016

Please cite this article as: Jespersen L., Griffiths M., Maclaurin T., Chapman B. \& Wallace C.A, Measurement of Food Safety Culture using Survey and Maturity Profiling Tools, Food Control (2016), doi: 10.1016/j.foodcont.2016.01.030.

This is a PDF file of an unedited manuscript that has been accepted for publication. As a service to our customers we are providing this early version of the manuscript. The manuscript will undergo copyediting, typesetting, and review of the resulting proof before it is published in its final form. Please note that during the production process errors may be discovered which could affect the content, and all legal disclaimers that apply to the journal pertain. 


\title{
Measurement of Food Safety Culture using Survey and Maturity
}

\section{Profiling Tools}

\author{
Author names and affiliations \\ Lone Jespersen, University of Guelph(1), Dr. Mansel Griffiths, University of Guelph (1), Dr. Tanya Maclaurin, \\ University of Guelph (1), Dr. Ben Chapman, North Carolina State University (2), and Prof. Carol A Wallace, University \\ of Central Lancashire (3).
}

(1) University of Guelph, 50 Stone Road East, Guelph, ON, N1G 2M7, Canada (2) North Carolina State University, Raleigh, NC 27695, United States, (3) University of Central Lancashire, Preston, Lancashire PR1 2HE, United Kingdom.

\section{Corresponding author}

Lone Jespersen, University of Guelph, 50 Stone Road East, Guelph, ON N1G 2M7, Canada. +41792460807. lone@uoguelph.ca
Abstract
Organizational culture is defined by dimensions and characteristics that can be used to measure food safety culture in food manufacturing through a food safety maturity model.
Maturity models from quality, health care, and information technology have been used since early 1970 and this work presents a novel food safety culture maturity model with five capability areas and food safety pinpointed behaviours specific to functions and levels in a food manufacturing company. A survey tool linked to the model is used to measure a company's position within the maturity model framework. The method was tested with a Canadian food 
21 manufacturer and proved valuable to measure food safety culture across the five capability areas,

22 which provides the manufacturer with a map for prioritizing future efforts to strengthen food

23 safety culture.

24

\section{Highlights}

- Theory of organizational culture was applied to measure food safety culture dimensions and characteristics

- Food safety culture was measured using a self-assessment survey with function and role specific pinpointed food safety behaviours

- A food safety maturity model was developed to measure food safety culture in food manufacturing

- The survey was tested with a Canadian food manufacturer across six meat plants resulting in a measure of the organization's food safety culture across six capability areas specific to food safety.

\section{Keywords}

Food safety, food safety culture, food manufacturing, food safety maturity model, capability areas, culture measurement. 


\section{Introduction}

The World Health Organization's Foodborne Disease Burden Epidemiology Reference Group estimated that there were 582 million cases and 351000 deaths associated with 22 different foodborne enteric diseases in 2010 (WHO FERG group, 2010). These diseases and deaths are often linked to a breakdown in food safety programs because of improper human behaviour or an appropriate food safety culture (Griffith, 2010a, Jespersen and Huffman, 2014). The issue remains how to minimize population exposure to foodborne pathogens. In addition, is known that older and immunocompromised members of society are more susceptible to foodborne illness (FDA, 2015; Lund and O'Brien, 2011). By 2035, the proportion of people over the age of 60 globally will have doubled from $11 \%$ (2012) to $22 \%$ (2035) (United Nations, Department of Economic and Social Affairs, 2012). Although this increase in the elderly population is generally seen as an indicator of global health, it is also a measure of a growing number of people who are vulnerable to infectious diseases, including foodborne infections or intoxications (International Union of Food Science and Technology (IUFoST), 2015). This, along with other disease trends, such as a 1.5-fold increase in the number of cases of diabetes expected during the same period (International Diabetes Federation, 2014), and continued foodborne illness outbreaks and recalls will maintain food safety as paramount for the near future.

The objective of this research was to develop a method to characterize and measure food safety culture. It was decided, based on the structure, content, and usage of existing maturity 
models, to develop a food safety maturity model and a behaviour-based method for assessing the performance of food manufacturers against the model.

\section{Organizational culture}

Food safety culture in food manufacturing is rooted in the definition, dimensions, and characteristics of organizational culture. Schein (2004) defines organizational culture as,

"A pattern of shared basic assumptions that was learned by a group as it solved its problems. The group found these assumptions to work well enough to be considered valid and, therefore, to be taught to new members as the correct way to perceive, think, and feel in relation to those problems."

Cultural dimensions and characteristics (Table 1) adapted from Schein's work serve as a theoretical framework to characterize an organization's food safety culture

\section{Food safety culture and food manufacturing}

Food safety culture has been discussed by various authors from general practices relating food safety culture to organizational leadership (Griffith, 2010b; Powell et al, 2011; Yiannas, 2009), to specific studies of connecting food safety culture to food safety climate (De Boeck et al, 2015). Studies have also investigated different behavioural techniques that can be applied within food safety culture and demonstrated that general psychological and behavioural frameworks can also be applied to the context of food safety (Yiannas, 2015; Taylor, 2010). Two measurement systems for assessing food safety climate and food safety culture have emerged (Wright, 2013; De Beock, 2015), one from the perspective of regulators (Wright et al) and, more recently, one 
for food processing organizations (De Boeck et al). Other commercial measurement systems (e.g.,Campden BRI/TSI, Taylor, 2015) exist and, although the measurement systems element of these may not have been subject to peer-review publication, they do add to the very important discussion of quantifying food safety culture. The work described here was constructed with a view to measuring food safety culture in manufacturing organizations.

Few food safety culture research studies have been completed in food manufacturing plants and the studies completed identify food safety culture as an interdisciplinary challenge that can be resolved by applying tools from cognitive social sciences to provide further knowledge about what drives food handlers to perform food safety behaviours (Hinsz, Nickell, \& Park, 2007; Wilcock, Ball, \& Fajumo, 2011). The reasoned action approach (Fishbein \& Ajzen, 2009) was applied to predict food handler behaviours in a turkey manufacturing plant. The study identified attitude, perceived norm, and perceived control as predictive variables of food handler behaviours (Hinsz, Nickell, \& Park, 2007). A follow up study proved that work habits also predicted food handler behaviours when confounded with the other reasoned action model variables, attitude, perceived control, and social norms. (Hinsz et al., 2007). To further explain what impacts food handlers to practices food safety behaviours Ball et al. (2009) studied the impact of working groups on food handler behaviours and found a significance relationship between the work units' commitment to food safety and food handler behaviours. The viability of using performance standards, e.g. audit reports, performance monitoring and audit records, to measure food safety culture was investigated by Jespersen et al. (2014), who suggested that data from performance standards were useful to assess food safety at a particular point in time but did not provide a complete measure of organizational food safety culture. This suggested that a 
101

102

103

104

105

106

107

measurement system using multiple methods and specific to food safety culture in food manufacturing should be developed against which manufacturers could measure their current state and progress of improving their food safety culture.

\section{Theories and perspectives}

Food safety culture it is proposed as the interlinking of three theoretical perspectives: organizational culture, food science and social cognitive science. Organizational culture is seen as different from other cultural definitions (e.g., geographical, national culture) (Hofstede, Hofstede, and Minkov, 2010) and consists of generic attributes such as artifacts, espoused values, beliefs, and ways to characterize culture regardless of the area, function or discipline (Schein, 2004). Performance of organizations can be measured using tools such as the Denison model where organizational culture and leadership are measured to diagnose an organizations effectiveness and as such is seen as a direct link to the financial performance of the organization (Denison, 2012). The food science perspective allows food-specific considerations, such as risks associated with food and how to measure and evaluate these. For example, food science enables the search for answers to questions of definition and quantification of risks associated with a given product and process. It includes risk management concepts, such as HACCP, to evaluate how an organization manages food safety risk through its long term management systems and daily decisions about product safety. An organization has to identify, assess, and mitigate hazards such as biological hazards e.g., pathogens such as Listeria monocytogenes, chemical hazards e.g., sanitation residue and pesticides, and physical hazards such as bones, stones, and metal fragments from manufacturing equipment. Social cognitive science can be applied to 
define, measure, and predict human behaviours. Methods from social cognitive science can be applied specifically to measure the intent of an organization, a manager, a team, and an individual to perform behaviours within the scope of the organization's own rules and values. For example, a manufacturer's value might be dare to be transparent, which could be translated into a behaviour such as: "Today I told a new colleague that he missed sanitizing his hands after washing and helped him understand why this is important to the safety of our food."

\subsection{Cultural dimensions.}

A number of authors have researched and written about organizational culture. Brown (1998) and Denison (1997) both cite the work of Edgar Schein as the one of the pioneers in dimensionalizing organizational culture. Principles from Schein has also been reviewed and applied in food safety to demonstrate the linkage between these proven principles and food safety culture (Griffith, 2010b).

Schein's five dimensions of organizational culture (Schein, 2004) were therefore chosen as the theoretical framework to organize the various theoretical perspectives, food safety capability areas, and food safety culture measures. Cultural dimensions can be applied to the study of organizational culture and are essentially defined across measurable characteristics. A dimension can be thought of as an area of the overall traits of organizational culture that contains components which can be actioned and measured for strength and effectiveness. By applying dimensions such as those defined by Schein it makes it simpler to understand what organizational culture is and how better to design measurements systems and actions to strengthen an organizations culture. Schein suggests five dimensions (Table 1). 

Schein, 2004 (Jespersen et al, 2014)

\section{Dimension}

External adaptation

Internal integration

Reality and truth

Time and space

Human nature, activity and relationship
Mission and goals, means (e.g., day-to-day behaviours, skills, knowledge, time and technology) to reach goals, degree of autonomy, how does the organization decide what to measure, measures (what and how), how to judge success, remediate and repair processes, and crisis history.

System of communication, common language, group selection and exclusion criteria, allocation systems (e.g., influence, power and authority), rules for relationships and systems for rewards and punishment.

High vs. low context, definition of truth, information, data, and knowledge needs; training and competencies; systems (e.g., sign-off), continuous improvement.

Four different dimensions for characterizing time orientation; assumptions around time management.

Theory $\mathrm{x} / \mathrm{y}$ managers, the doing/being/being-in-becoming orientation, and four basic problems solved in a group: identity and role; power and influence; needs and goals; acceptance and 


\section{Dimension}

Components

intimacy, individualism/groupism, power distance and accepted behaviours \& practices.

\subsection{Measuring using maturity models.}

Maturity models are tools to evaluate a current state of a given culture, system, business or process, and to develop improvement plans against a scale of maturity. Maturity models are most often specific to a subject matter (e.g., information technology or occupational health and safety) and wide ranges of industries have defined maturity models to improve effectiveness of organizational culture. A maturity model can help an organization understand how industry peers are performing and how this performance compares to its own. The model summarizes acceptable industry practices and allows the organization to assess what is required to reach a certain level of management and control of these practices. potential for measuring food safety culture. These were chosen as examples of maturity models that are topic/function specific not unlike food safety and also based on the great level of detail available for each model about their development and use. Each model was researched with emphasis on the results that the topic or function sought to improve. As such, the health care model was tied to health care organizations striving for and receiving the Baldridge Quality 
161 Award and the CobiT to organizations receiving IS Certification. Both were considered to

162 generate specific results through improved maturity in the organizations researched (Table 2).

Table 2: Stages/levels and assessment methods of maturity models applied to other disciplines

\begin{tabular}{lll}
\hline Maturity Model (Name) & Stages/Levels & Assessment Method \\
\hline Quality management & Five stages; Uncertainty, & Subjective assessment by \\
(Quality Management & Awakening, Enlightenment, & raters \\
Grid) & Wisdom, and Certainty & \\
Health care (Baldridge) & Five stages; Reaction, & Document reviews, audits, \\
& Projects, Traction, & and interviews \\
& Integration, and Sustaining & \\
Information technology & Six levels; Non-existent, & Third party assessors \\
& Initial/ad hoc, Repeatable & through procedural reviews \\
& but Intuitive, Defined & and interviews \\
& Process, Managed and & \\
& Measurable, and Optimized & \\
& PobiT) &
\end{tabular}

In 1972 Crosby first published "Quality is Free” (Crosby, 1972). In this work, he presents 
169

170

171

172

173

174

175

176

177

178

179

180

181

182

183

184

programs in quality can be deduced through Crosby's Management Maturity Grid. Anyone can spend a few minutes with the grid, decide where an organization is currently positioned, and know what needs to be done to move forward. The grid is divided into five stages of maturity and six management categories serve as the experience relations that anyone must go through to complete the matrix. By reading the experience condensed in each block within the grid, it is possible for the reader to assess a specific organization's quality management culture. Crosby recommended that the assessment was done separately by three managers and compared; nevertheless, it is recognised that this is a subjective evaluation of maturity (Crosby, 1972). In the food industry, food safety management and quality management are considered to be closely related and food safety is often thought of as a subset of quality (Mortimore \& Wallace, 1994; Rohr et al, 2005). The Quality Management Maturity Grid is, therefore, a logical starting point when developing a maturity model for food safety.

\subsubsection{Health Care.}

Goonan et al. (2009) describe the journey taken by health care organizations towards receiving a Baldridge award. The Baldridge award is part of the U.S. National Quality Program and the Malcolm Baldridge National Quality Improvement Act, which was signed into law in 1987. The focus of the program is to help companies improve quality and productivity and recognize these achievements as an example for others to follow. The program has established guidelines with evaluation criteria and provides specific guidance to companies who wish to improve quality and pursue the Baldridge award. While none of the recipients characterized 
receiving the award as the "silver bullet", most described it as an opportunity to seek a systems model to help unify to one common framework (Goonan, Muzikowski, \& Stoltz, 2009).

The maturity model developed by Goonan et al. (2009) describes a specific journey to performance improvement and the maturity model specifies the content of this journey for health care organizations. The assessment against the maturity model is through document reviews and visits to the organizations for system audits and interviews. This multi-method approach is not unlike that carried out in food safety by third party auditors against food safety standards such as SQF and FSSC22000.

\subsubsection{Control Objectives for Information and related Technology.}

Control Objectives for Information and Related Technology (CobiT) (“COBIT 5”, 2014) develops and maintains tools, such as maturity models, performance goals, and metrics and activity goals for use within the information technology industry. The maturity model, as defined by CobiT, has five maturity stages and six attributes; (1) Awareness and communication, (2) Policies, plans and procedures, (3) Tools and automation, (4) Skills and expertise, (5) Responsibility and accountability, and (6) Goal setting and measurements.

A generic definition is provided for the maturity scale and interpreted for the nature of CobiT's IT management processes. A specific maturity model is provided for each of CobiT's 34 processes. The purpose is to identify issues and set improvement priorities. The processes are not designed for use as a threshold model where one cannot move to the next higher level without having fulfilled all conditions of the lower level, rather as a practical and easy to understand maturity scale that can facilitate raising awareness, capture broader consensus, and motivate 
improvement. Thus, the maturity model is a way to measure how well developed the management process and supporting culture is.

As shown in the above review, maturity models are already used to characterize a given area of focus (e.g., quality, health care culture, and information technology) and through definition of specific areas that the subject matter area has deemed important for an organization to demonstrate capability within. A maturity model can also be used to measure a process or an organization's current state and thereby help prioritize the actions needed to progress. The following learnings can be derived from each of the models described, (1) culture can be segmented into areas of focus to a specific area such as food safety, (2) maturity of culture can be linked to results and performance, (3) structure of five levels/stages of maturity and five to seven focus areas have been successfully applied to improve performance in health care and IS/IT. Thus it is likely that a similar structure could be useful for measuring food safety culture performance and maturity. The models reviewed used a variety of assessment approaches to pinpoint an organisations position (maturity profile) within the given model, including management rating (Crosby, 1972) document review and site assessment (Goonan, Muzikowski, $225 \&$ Stoltz, 2009) and $3^{\text {rd }}$ party audit (COBIT 5, 2014). Although the models are intended to indicate maturity of culture and performance, there are few behaviour-based elements in the assessment processes. This would seem to be an oversight since behaviour is understood to play a major role in culture (Hofstede, Hofstede, and Minkov; Schein, 2004; Denison, 2015; Yiannas, 2015).Work on social cognitive models (Hinsz et al, 2007; Ball et al, 2009) suggests that 230 behaviour-based assessment can give a useful measure as part of food safety assessment. 
231 Therefore, a behaviour-based maturity profile approach might provide an effective measure of an 232 organisation's food safety culture.

\section{3} $1)$.


242

\section{Method}

Two methods were applied, a modified Delphi method and definition of pinpointed behaviours based on Ajzen and Fishbein's characteristics of behaviours (Fishbein \& Ajzen, 2009). The modified Delphi consisted of three rounds of feedback where panel members were asked to provide feedback through group discussion. The feedback was integrated into the maturity model after each round. An industry panel was established to lead in the development of the content of the model and behaviours were developed with input from a social scientist to assist in breaking down the individual components of the model to pinpoint and simply define behaviours (Figure


\section{Figure 1: Cascading process for development of the components of the measurement system}

The capability areas, and the subsequent food safety maturity model, were developed with the panel of industry experts. The experts were selected based on their practical experience in food safety leadership within international food manufacturing organizations. The experience 
and knowledge of leaders in food manufacturing was critical to ascertain the practical input into the definition of capability areas and the pinpointed behaviours as there was no existing published food safety maturity model. The individual expert panel members were chosen based on their demonstrated knowledge, experience, and leadership. A seven-person panel was identified to meet quarterly during the development phase of the maturity model.

\subsection{Development of Capability Areas.}

The purpose of a capability area is to translate an organizational cultural dimension into areas of specific importance to food manufacturers. Each theoretical perspective was mapped to a culture dimension. This mapping was used to provide guidance during the modified Delphi sessions for the industry experts to ensure linkage between the food safety capability areas and dimensions of organizational culture (Table 3). For example, the organizational cultural dimension reality and truth was translated into specific language used in food manufacturing and content related to e.g., measurement systems, and data captured in the technology enabled capability area. A capability area is defined as "an area thought to be critical to food safety

Table 3: Mapping theoretical perspective to organizational cultural dimensions and food safety capability areas

\begin{tabular}{l|l|l}
\hline Theoretical perspective & Culture dimensions & Capability areas \\
\hline Organizational culture & External adaptation & Perceived value \\
& Internal integration & People systems
\end{tabular}




\begin{tabular}{l|l|l}
\hline Theoretical perspective & Culture dimensions & Capability areas \\
\hline Social cognitive science & Human nature, activity, and & People systems \\
& relationship & \\
& Human nature, activity, and & Process thinking \\
\hline Food science & Reality and truth & Technology enabled \\
& Reality and truth & Tools and infrastructure \\
\hline
\end{tabular}

Five capability areas define the core of the food safety culture measurement system. Each capability area was further defined individually on a scale of maturity in the food safety maturity model. One of Schein's dimensions - time and place - was found through the expert panel not to be of specific relevance to food safety and through the Delphi method it was decided to exclude this in the food safety capability areas.

There are five stages of maturity in the model. Stage 1 is Doubt and is described by

274 questions such as "Who messed up?" and "Food safety - QA does that?" Stage 2 is React to and 275 described by questions and situations such as "How much time will it take?" and "We are good 276 at fire-fighting and reward it." Stage 3 is Know of and is described by statements such as "I know 277 it is important but I can fix only one problem at a time." Stage 4 is Predict and described by 278 statements such as "Here we plan and execute with knowledge, data and patience." Stage 5 is 
Internalize and described by situations such as "Food safety is an integral part of our business."

The Perceived value describes the extent to which food safety is seen as a regulatory requirement only (stage 1) or as critical to business performance and sustainability (stage 5). The People system describes an organization, which is task-based and lacks clearly defined accountabilities (stage 1) or an organization that clearly defines accountabilities and behaviour-based working groups (stage 5). Process thinking describes how the organization solves problems as independent tasks when problems occur (stage 1) or one where problem solving is seen as an iterative process built on critical thinking skills and data (stage 5). Technology enabled describes how the organization turns data into information as a manual and fragmented task (stage 1) or automatically and part of a company-wide information system (stage 5). Tools and infrastructure describes the availability of resources and can be illustrated as whether an employee needs to walk far to a sink (stage 1) or sinks are conveniently located (stage 5).

\subsection{The pinpointed behaviours and the behaviour-based scale.}

An inventory of behaviours was defined based on the descriptor in each maturity stage and capability area. The inventory was discussed with food safety and operations leaders in the company where data were collected and those behaviours believed to have the most impact on the descriptor in the maturity model were identified following discussion by the expert industry panel. Pinpointed behaviours can be thought of as those behaviours that are most likely to impact a given result, in this case food safety performance. The pinpointed behaviours in the maturity model were defined at two stages of maturity; doubt and internalized. By defining pinpointed behaviours at the endpoints of the maturity model it was possible to create a self-assessment 
300

301

302

303

304

305

306

307

308

309

310

311

survey with fewer questions and, by use of a 1-5 Likert scale, measure across the entire maturity model.

The objective of the questionnaire was to gather participant's self-assessment results against the pinpointed behaviours and collect demographic data pertaining to plant, function group, and work role. Each participant was asked to rate their own behaviour against a series of questions and statements. The answers to the self-assessment scale were analyzed based on demographics and behaviour predicting variables (attitude, perceived control, social norm and past behaviour and intention).

Each statement in the questionnaire was constructed in a standardized format for each pinpointed behaviour. For example, a question regarding the variable attitude would read "My behaviour to always design my own tools to gather food safety data is..." and the participant was asked to rate how strongly this reflected the respondent's attitude on a scale from 1 (beneficial) to 5 (harmful). Every question related to the variable attitude was structured in this way and rated on similar scales (Table 4).

Table 4: Variable and statement format for describing pinpointed behaviours

\begin{tabular}{lll}
\hline Variable & Standard start & Example pinpointed behaviour \\
\hline Attitude & My behaviour to $\ldots$ & $\ldots$ always design my own tools e.g. \\
& spreadsheet to gather food safety \\
& data...
\end{tabular}

Perceived I am confident that for the $\quad$...always design my own tools e.g. 
Control next three months I will ... $\quad$ spreadsheet to gather food safety data

Social Norm Most people, outside -and ...always design my own tools e.g. at work, whose opinion I spreadsheet to gather food safety value would approve of $\ldots \quad$ data

Past Behaviour I have in the past three ...always design my own tools e.g. months ... spreadsheet to gather food safety data

Behavioural I intend to ... ...always design my own tools e.g. Intent spreadsheet to gather food safety data

\subsection{Pinpointed behaviours.}

Behaviours were defined specific to function and roles and were used in the self-

318 assessment scale to determine maturity level (Table 5). As such, a Food Safety and Quality

319 supervisor might associate with the following behaviour "I rarely have time to identify root cause of problems and mostly find myself firefighting." This behaviour is the pinpointed behaviour for the process thinking capability area when the supervisor finds her or himself at the maturity stage of doubt. If the supervisor found her or himself in the maturity stage of internalized within the 
process thinking capability area the behaviour "I collect, analyze and report food safety data daily to plant staff to bring transparency to emerging challenges" might resonate better. context and timing for consistency and specificity in the definition of each of the behaviours (Fishbein \& Ajzen, 2009). For example, "I always design my own tools to gather food safety data," may represent a pinpointed behaviour for the Food Safety supervisors in a maturity stage of doubt and within the capability area technology enabled. The list of pinpointed behaviours cannot be considered an exhaustive list but were determined to be a list of critical behaviours in each maturity stage and capability area for the individual function and role. 
Table 5: Sample pinpointed behaviours for the food safety and quality function by role for the People System capability area in the maturity stages of doubt and internalized

\begin{tabular}{|c|c|c|c|c|}
\hline Capability area & $\begin{array}{l}\text { Supervisor } \\
\text { (Execute) }\end{array}$ & $\begin{array}{l}\text { Leader } \\
\text { (Tactic) }\end{array}$ & $\begin{array}{l}\text { Functional Leader } \\
\text { (Strategy) }\end{array}$ & Executive (Vision) \\
\hline $\begin{array}{l}\text { People System } \\
\text { (DOUBT) }\end{array}$ & $\begin{array}{l}\text { I immediately } \\
\text { remove food safety } \\
\text { issues by myself to } \\
\text { avoid negative } \\
\text { consequences for my } \\
\text { team and myself. }\end{array}$ & $\begin{array}{l}\text { I provide my direct } \\
\text { reports with } \\
\text { direction to remove } \\
\text { food safety problems } \\
\text { immediately to avoid } \\
\text { negative }\end{array}$ & $\begin{array}{l}\text { I always have to } \\
\text { manage negative } \\
\text { consequences when } \\
\text { a food safety } \\
\text { problem occurs. }\end{array}$ & $\begin{array}{l}\text { I make sure } \\
\text { somebody is } \\
\text { managing negative } \\
\text { consequences every } \\
\text { time a food safety } \\
\text { problem occurs. }\end{array}$ \\
\hline $\begin{array}{l}\text { People System } \\
\text { (INTERNALIZED) }\end{array}$ & $\begin{array}{l}\text { I take action daily to } \\
\text { let anybody know } \\
\text { when they go over } \\
\text { and beyond for food } \\
\text { safety. }\end{array}$ & $\begin{array}{l}\text { I take action daily to } \\
\text { provide positive } \\
\text { feedback when } \\
\text { others take action to } \\
\text { remove perceived } \\
\text { food safety risks. }\end{array}$ & $\begin{array}{l}\text { I take action daily to } \\
\text { complement my } \\
\text { peers in other } \\
\text { functions of their } \\
\text { demonstrated food } \\
\text { safety ownership. }\end{array}$ & $\begin{array}{l}\text { I minimum monthly } \\
\text { check in with } \\
\text { functional - and } \\
\text { business leaders to } \\
\text { ensure food safety is } \\
\text { built into their } \\
\text { business plans. }\end{array}$ \\
\hline
\end{tabular}

\subsection{The food safety maturity model.}

The food safety maturity model (Table 6) was developed based on the findings of the

343 literature review and input from the industry expert council. 
344 Each intersection of a capability area (e.g., perceived value) and a stage (e.g., doubt) was

345 defined by completing the sentence "We [STAGE] food safety and our [CAPABILITY AREA]

346 are described by X." For example, in the case of doubt the perceived value X would become

347 "completing tasks because regulations make us." Each definition was discussed and the industry

348 expert panel reached a consensus on the most important one or two definitions but did not

349 produce a comprehensive list of definitions, as this was thought to be of little value when

350 defining a measurement system. 
Table 6: Food Safety Maturity Model

\begin{tabular}{|c|c|c|c|c|c|}
\hline & \multicolumn{5}{|c|}{ Stage name } \\
\hline Capability Area & $\begin{array}{l}\text { Stage } 1 \\
\text { Doubt }\end{array}$ & $\begin{array}{l}\text { Stage } 2 \\
\text { React to }\end{array}$ & $\begin{array}{l}\text { Stage } 3 \\
\text { Know of }\end{array}$ & $\begin{array}{l}\text { Stage } 4 \\
\text { Predict }\end{array}$ & $\begin{array}{l}\text { Stage } 5 \\
\text { Internalize }\end{array}$ \\
\hline Perceived Value & $\begin{array}{l}\text { Completing tasks } \\
\text { because regulators make } \\
\text { us do so. } \\
\text { Food safety performance } \\
\text { data is not collected and } \\
\text { reported regularly to all } \\
\text { stakeholders. }\end{array}$ & $\begin{array}{l}\text { Little to no investment in } \\
\text { systems (people and } \\
\text { processes) to prevent food } \\
\text { safety firefighting. } \\
\text { Little understanding of true } \\
\text { food safety performance. }\end{array}$ & $\begin{array}{l}\text { Food safety issues are } \\
\text { solved one at a time, } \\
\text { getting to the root of the } \\
\text { issue, to protect the } \\
\text { business. } \\
\text { Strong, databased } \\
\text { understanding of true } \\
\text { food safety performance. }\end{array}$ & $\begin{array}{l}\text { Reoccurrence of food } \\
\text { safety issues is prevented } \\
\text { by used of knowledge and } \\
\text { leading indicators. }\end{array}$ & $\begin{array}{l}\text { Ongoing business } \\
\text { improvement and growth } \\
\text { is enabled by food safety. }\end{array}$ \\
\hline
\end{tabular}




\begin{tabular}{|c|c|c|c|c|c|}
\hline People System & $\begin{array}{l}\text { Tasks are only } \\
\text { completed when senior } \\
\text { leader's demand, } \\
\text { without understanding } \\
\text { responsibility, the task, } \\
\text { or why it is important. } \\
\text { Tasks being completed } \\
\text { out of fear for negative } \\
\text { consequences. } \\
\text { Top management having } \\
\text { to individually certify } \\
\text { the accuracy of food } \\
\text { safety information. }\end{array}$ & $\begin{array}{l}\text { Responsibilities for } \\
\text { problems are established as } \\
\text { the problems are } \\
\text { discovered and solved } \\
\text { mostly by use of negative } \\
\text { consequences. } \\
\text { Tools are invented as new } \\
\text { problems arise and the tools } \\
\text { are rarely incorporated into } \\
\text { systems for future use. }\end{array}$ & $\begin{array}{l}\text { Deeper understanding for } \\
\text { the importance of foods } \\
\text { safety systems, where } \\
\text { responsibilities are } \\
\text { clearly defined and } \\
\text { communicated, is gained } \\
\text { one issue at a time. } \\
\text { Consequences are mostly } \\
\text { managed when mistakes } \\
\text { happen, seldom through a } \\
\text { defined plan, with both } \\
\text { positive and negative } \\
\text { consequences. }\end{array}$ & $\begin{array}{l}\text { Develop and assess tools } \\
\text { for improving processes } \\
\text { through knowledge and } \\
\text { data. } \\
\text { Responsibilities and } \\
\text { accountabilities are } \\
\text { discussed, communicated, } \\
\text { and assessed with } \\
\text { patience. } \\
\text { Processes are developed, } \\
\text { including consequences } \\
\text { (positive and negative), } \\
\text { and managed preventive } \\
\text { through communication } \\
\text { and assessment. }\end{array}$ & $\begin{array}{l}\text { Strategic direction is set } \\
\text { across the complete } \\
\text { organization with } \\
\text { defined accountabilities, } \\
\text { responsibilities, and food } \\
\text { safety as one of the } \\
\text { business enablers. } \\
\text { Preventive definition and } \\
\text { continuous improvement } \\
\text { of specific food safety } \\
\text { behaviours, } \\
\text { consequences and tools. }\end{array}$ \\
\hline
\end{tabular}

Page 24 of 41 


\begin{tabular}{|c|c|c|c|c|c|}
\hline Process Thinking & $\begin{array}{l}\text { Unstructured problem } \\
\text { solving to remove the } \\
\text { immediate pain. }\end{array}$ & $\begin{array}{l}\text { "Plan, Do, Check, Act" } \\
\text { with emphasis on control in } \\
\text { the check phase and } \\
\text { expectation of an } \\
\text { immediate } 100 \% \text { perfect } \\
\text { solution. }\end{array}$ & $\begin{array}{l}\text { Structure problem solving } \\
\text { with significant risk of } \\
\text { over analyzing. }\end{array}$ & $\begin{array}{l}\text { "Plan, Do, Study, Act" } \\
\text { with emphasis on study } \\
\text { and not control. Problem } \\
\text { solving is accepted as an } \\
\text { iterative process. }\end{array}$ & $\begin{array}{l}\text { Horizon scanning and } \\
\text { continuous improvement } \\
\text { are used to identify risks. } \\
\text { Risks inform the } \\
\text { development and/or } \\
\text { improvement of } \\
\text { mitigation plans. } \\
\text { Mitigation plans are } \\
\text { integrated in the global } \\
\text { business management } \\
\text { system. }\end{array}$ \\
\hline
\end{tabular}




\begin{tabular}{|c|c|c|c|c|c|}
\hline $\begin{array}{l}\text { Technology } \\
\text { Enabled }\end{array}$ & $\begin{array}{l}\text { Little technology being } \\
\text { adopted and few see this } \\
\text { to be an issue. }\end{array}$ & $\begin{array}{l}\text { Responsibility is left to the } \\
\text { individual to identify data } \\
\text { needed and there is a high } \\
\text { reliance on the individual to } \\
\text { derive information from the } \\
\text { data. }\end{array}$ & $\begin{array}{l}\text { Standard technology is } \\
\text { adopted on going and } \\
\text { standardized training } \\
\text { provided to individuals as } \\
\text { needed. } \\
\text { It is unlikely to see that } \\
\text { issues are prevented by } \\
\text { use of data-driven } \\
\text { information. }\end{array}$ & $\begin{array}{l}\text { Data is collected in a } \\
\text { precise and accurate } \\
\text { manner to constantly } \\
\text { improve processes. } \\
\text { Automation is used in a } \\
\text { limited or fragmented } \\
\text { way. }\end{array}$ & $\begin{array}{l}\text { Integrated, global } \\
\text { information systems } \\
\text { (e.g., ERP) are in place } \\
\text { in the organization } \\
\text { making it quick to adapt, } \\
\text { improve, and use } \\
\text { automated workflows. }\end{array}$ \\
\hline $\begin{array}{l}\text { Tools and } \\
\text { Infrastructure }\end{array}$ & $\begin{array}{l}\text { Minimal tools in the } \\
\text { hands of few } \\
\text { individuals. }\end{array}$ & $\begin{array}{l}\text { It takes a problem to get the } \\
\text { right tools. This often leads } \\
\text { to findings the right tools in } \\
\text { a hurry and resulting in } \\
\text { rework. }\end{array}$ & $\begin{array}{l}\text { The organization invests } \\
\text { readily in the right tools } \\
\text { and infrastructure when } \\
\text { solving a problem calls } \\
\text { for it. }\end{array}$ & $\begin{array}{l}\text { Food safety tools and } \\
\text { infrastructures are in place } \\
\text { and are continuously } \\
\text { improved for ease of use } \\
\text { and cost of the } \\
\text { organization. }\end{array}$ & $\begin{array}{l}\text { Investment in tools and } \\
\text { infrastructure is } \\
\text { evaluated long-term and } \\
\text { prioritized along with } \\
\text { other business } \\
\text { investments. }\end{array}$ \\
\hline
\end{tabular}


MEASURING FOOD SAFETY CULTURE IN FOOD MANUFACTURING.

\subsection{Questionnaire administration.}

Data were collected from a Canadian food manufacturing company between February

and April 2014. The company employed approximately 19,000 employees across 47 plants at the

questionnaire was constructed to gather data for all capability areas in the food safety maturity

model. The scale was administered through an online survey tool, all responses were anonymous,

and each respondent was rewarded with a $\$ 5$ product voucher for their participation. Employees in supervisory roles and leadership positions $(n=1,030)$ within the two functions food safety and quality and manufacturing were given the opportunity to participate. Survey responses were received from 219 employees ( $21.3 \%$ response rate). The responses from the questionnaires were analyzed after import into Minitab 10 (Minitab Inc. State College, PA) using a numbering convention to ensure anonymity. Minitab 10 is a general-purpose statistical software package designed as a primary tool for analyzing research data. The examination of the data was conducted using descriptive statistical principles and statistical tests (e.g., ANOVA) to explore differences between levels, roles, plants, and maturity stages.

\section{Results}

\subsection{Overall company behaviour-based maturity.}

373 of. The capability areas perceived value and tools and infrastructure scored the highest average

374 scores of 3.1 in both areas. The capability areas people systems and process thinking scored 
375 within the maturity stage of react to just ahead of the capability area technology enabled also

376 within the maturity stage of react to. Mean maturity scores for each capability area and range

377 (minimum and maximum average by plant) were plotted on the maturity model (Figure 2).

379 stages of maturity across the top. Based on the results from the questionnaire the mean, min, and

380 max score are calculated and plotted against each capability area. The numeric scale (0.1-5.0) is

381 show below the maturity stage identifiers. For example, the mean score for the company in the

382 study for perceived value is 3.1 with minimum score of 2.9 and maximum score of 3.2. 
Figure 2: Overall company behaviour-based maturity



Page 29 of 41 
Overall, a significant difference $(p=0.003)$ was found between maturity perceived by the

386 food safety and quality function $(n=306)$ and the manufacturing function $(n=724)$. A difference

387 was found for one of the five capability areas, namely technology enabled, with the manufacturing function rating the enablement through technology at a higher maturity than the food safety and quality function. The data collected by role, supervisory $(\mathrm{n}=890)$, leader $(\mathrm{n}=$ 223), and functional leader $(n=98)$, showed a significant $(\mathrm{p}<0.001)$ difference in overall maturity, leaders ranked maturity the highest on the maturity scale (mean $=2.096)$ in know of,

392 followed by functional leader (mean $=2.080$ ) in know of, and lastly supervisors who ranked 393 maturity the lowest $($ mean $=1.983)$ in react to.

\subsection{Plant behaviour-based maturity.}

Plant specific data were plotted on the maturity model and the difference between the

396 plant's overall maturity score was analyzed using a one-way ANOVA analysis. It was

397 determined that there was a statistically significant difference between one or more of the plants $398(\mathrm{p}<0.001)$.

Mean maturity score was calculated for overall maturity of the plant and by capability

400 area. The percentage of maximum score (5) for each plant's overall maturity was calculated as a 401 measure of the strength of an individual plant's food safety culture (Table 9). 


\section{Capability Area}

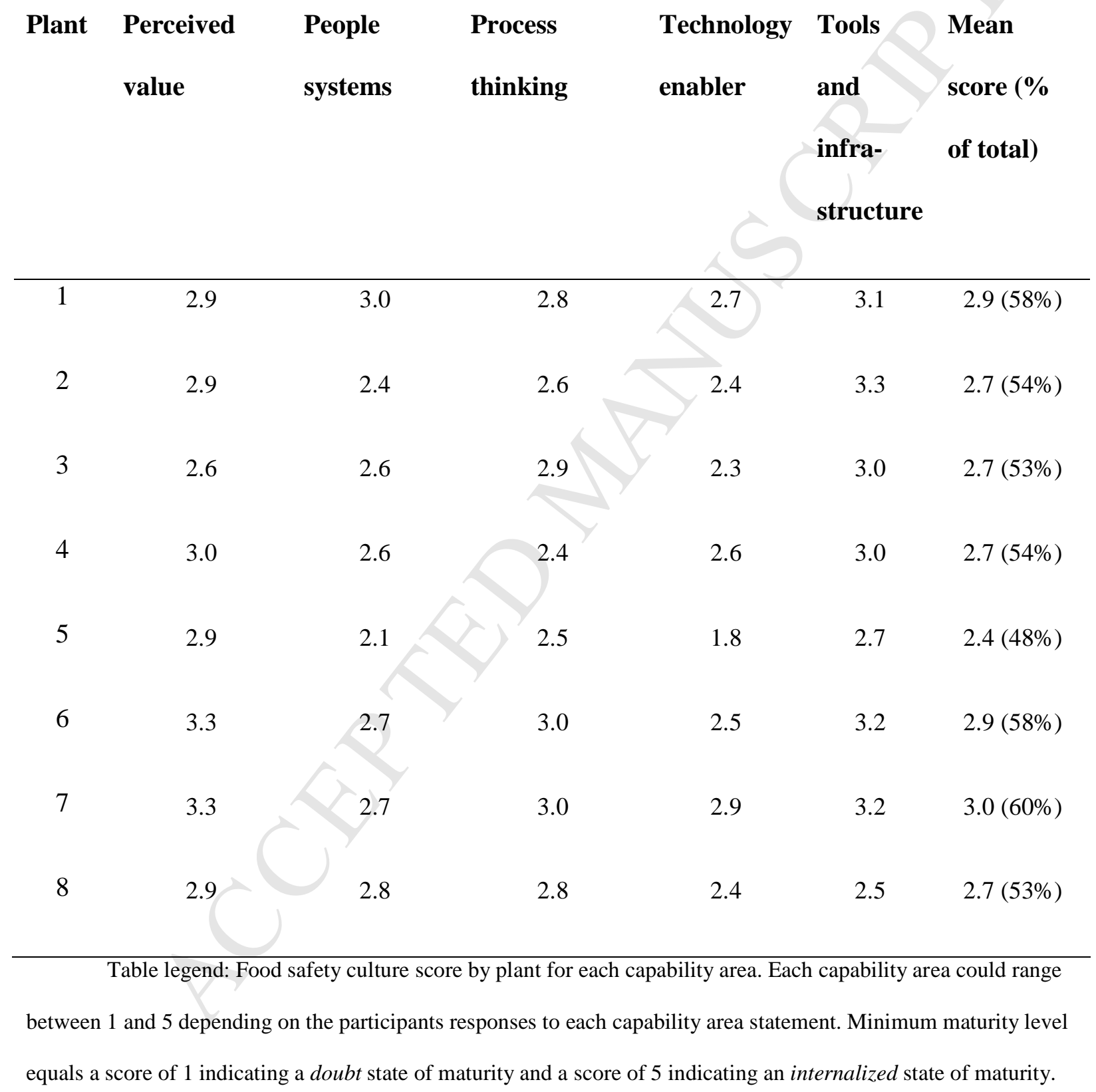


Average for each plant was calculated and a percentage achieved calculated to quantify strength of each plants food safety culture.

The results show the average maturity of the eight plants is between stages react to and know of. Three plants (P1, P6, and P7) had the strongest food safety culture with scores between $58 \%$ and $60 \%$ ranging from $2.9-3.0$ in average maturity score. Extrapolating from these scores and the food safety maturity model, the culture in these plants can be described as one where food safety issues are solved one at a time and a solid understanding of food safety performance through data acquisition and analysis exists. There is a clear understanding of responsibility and consequences are mostly managed when a problem occurs. These plants make good use of data but sometimes over analyze issues. Technology has been adopted to help manage food safety systems but it is unlikely that these plants use data to prevent problems from occurring. Investments in tools and infrastructure are made when required to solve a problem.

The plant (P5) with the lowest score (48\%) was placed in the react to stage. The culture in this plant can be described as one where there is little to no investment in food safety and the perceived value of such an investment is not clear. Responsibility for problems is assigned as they occur and antecedents (e.g., training, job descriptions, and performance measures) are developed in reaction to food safety problems. Problems are solved as they arise and there is little evidence of systematic continuous improvement. In this plant, the responsibility to decide what data to collect is placed on the individual and not the group and decisions for investment in tools and infrastructure change are made as new problems arise. 


\section{Discussion and conclusions}

The purpose of this research was to search for ways to characterize and measure food safety culture. Some research and publications are available linking food safety culture to factors such as leadership, communications, and learning (Griffith, 2010b; Powell et al, 2011; Yiannas, 2009a). A few studies propose methods for assessing food safety climate and food safety culture (De Beock, 2015,Taylor, 2015,Wright, 2013) and another few have conducted detailed research specific to behaviours in food manufacturing (Ball, Wilcock, \& Aung, 2009; Nickell \& Hinsz, 2011). The results of this research applied dimensions and characteristics found in organizational culture theory to measure and explain maturity of food safety in food manufacturing organizations. A behaviour-based food safety maturity model was applied as a method to measure food safety culture and this was tested at the case study organization.

The food safety maturity model was built on the experience of a food safety industry expert panel and knowledge acquired from maturity models applied to other disciplines (e.g., quality management, health care, and information technology). The overall food safety culture was measured using a behaviour-based scale derived from the reasoned action model (Fishbein \& Ajzen, 2009) and the food safety specific maturity model stages.

As a result of applying the food safety maturity model and behaviour-based scale, the food safety culture for plants in this specific company ranges between maturity stage 2 react to and maturity stage 3 know of. The organization finds itself in a stage of maturity where food safety is accepted as an important part of business, decisions are increasingly made based on 
science and data, training is increasingly standardized, and investment in infrastructure and tools are readily available as needs arise. There is a tendency to not invest in systems (protocols or technology); to assign responsibility for problems as problems arise, and on occasion, the company reacts to problems more than prevents them.

Mapping of the food safety capability areas of the food safety maturity model to Schein's Culture dimensions (Schein, 2004) and the theoretical perspectives on food science, social cognitive science and organisational culture was shown in Table 3. Considering the company's overall food safety culture position between stages 2 (React to) and Stage 3 (know of), this illustrates a culture where the organisational cultural dimentions of Internal Integration and Human Nature, activity and relationship are at a level where individuals have limited power, problem solving has emphasis on control of checking and responsibility for problems is generally solved by the use of negative consequences. External Adaptation relates to food safety firefighting to solve crises one at a time, and Reality and truth shows a high reliance on the individual to derive meaning from data although the organisation is willing to invest in tools and infrastructure if solving a problem calls for it. Knowing this, the company can now make informed decisions on where resources should be allocated to make the most important change in the strength of the organization's food safety culture. Also, the organization can cross-reference to generic organizational culture to ensure improvments are made to food safety as an integrated part of overall organizational culture. For example, the organizations score showed a statistically significant difference between leaders and supervisors perception of food safety maturity. This 
467

was especially shown in People Systems (cross-referenced to Internal Integration.) To action this the organization can look at their overall strategies, structure, and processes related to supervisors and make use of the food safety findings to improve that the translation of food safety policies through the supervisory group.

Maturity models are widely used in organizations to improve processes and cultures (Crosby, 1972; Goonan et al., 2009), however, no maturity model had previously been developed specifically for food safety culture. Two published assessment tools were reviewed and brought insight into the assessment of food safety climate (De Boeck et al., 2015) and assessments of food safety culture by regulatory inspectors in small manufacturing (Wright, 2013). However, it is believed there is still a gap of food safety culture measurement tools specific to food manufacturing built on organizational theory which the maturity model described here aims to fill. The findings of this study are unique in that they highlight potential for incorporating a behaviour-based maturity model into a food safety measurement system. This will provide an indication as to how well an organisation's employees know of and deal with issues related to food safety as well as depicting the state of the organization and its performance specific to food safety.

A key feature of this novel food safety maturity model approach is that it combines the maturity profiling and behavioural-based approaches and thus provides a cultural element to food safety maturity estimates. Performance scoring systems such as the Baldridge award follow a similar maturity model approach but, in contrast to the present study, the Baldridge model does 
not take specific food safety requirements or situations into account, nor does it give a behaviorbased analysis from the perception of the workforce. Behaviour-based studies have proved the applicability of social cognitive models to assess food safety behaviours (Ball, Wilcock, \& Aung, 2009; Nickell \& Hinsz, 2011) and these studies clearly indicate the opportunity for the use of these models in food safety, although they have not previously been used as part of maturity profiling. By putting these two areas together, this behaviour-based food safety maturity profile tool could be embedded into food safety management systems monitoring and verification, giving an objective measure of the food safety culture from the perspective of the workforce functions and roles to be considered alongside objective views of the effectiveness of food safety management system elements provided by, for example, third party audit.

Given the lack of a control group or other validation activities in this study, it cannot be concluded that the self-assessment score covers all characteristics of food safety culture. For future studies, additional validation activities such as semi-structured interviews and group based behavioural observations at a participating plant could validate the findings. The research was conducted within one food manufacturing organization and without the opportunity to compare with other organizations. Therefore, it is not possible to say at this stage if the measurement system is robust enough to detect differences caused by the individual organization, its geographical location, and the role it plays in the global food chain (e.g., grower versus manufacturer versus retailer). It is recommended that further research be carried out to validate 
the measurement system and test the model's applicability to assess food safety culture across multiple organizations.

The measurement system developed in this research can be used as a practical tool for manufacturers to assess the strength of their food safety culture and allocate resources in those areas that need it the most in this changing environment. It is also a system that can help

511 organizations to tie food safety into their overarching organizational culture, thereby linking food

512 safety to overarching organizational effectiveness. In this way the food safety culture maturity

513 profiling tool could bring clarity and benefit to many organizations in the global food

514 manufacturing industry.

\subsection{Acknowledgements}

The researchers would like to acknowledge Dr. John Butts, Raul Fajardo, Martha Gonzalez, Holly Mockus, Sara Mortimore, Dr. Payton Pruett, John Weisgerber, and Deirdre Conway for

518 their contributions. Special thanks to Dr. Randy Huffman for his on-going support and 519 encouragement. 
Ball, B., Wilcock, A., \& Aung, M. (2009). Factors influencing workers to follow food safety management systems in meat plants in ontario, canada. International Journal of Environmental Health Research, 19(3), 201-218. doi:10.1080/09603120802527646

Brown, A. (1998). Organizational Culture, Financial Times Management; 2 edition (June 1998).

Crosby, P. B. (1972). Quality is free, McGraw-Hill.

Denison, D. R. (1997). Corporate Culture and Organizational Effectiveness, Denison Consulting; 2nd edition (May 1997).

Denison, D. R. H. N. L., and Colleen Lief (2012). Leading Culture Change in Global Organizations: Aligning Culture and Strategy. John Wiley \& Sons.

E. De Boeck, L. J., M. Bollaerts, P. Vlerick (2015). "Food safety climate in food processing organizations: Development and validation of a self-assessment tool." Trends in Food Science \& Technology 46(2015): 242-251.

\section{http://www.fda.gov/Food/FoodborneIllnessContaminants/PeopleAtRisk/ucm352830.htm}

Fishbein, M., \& Ajzen, I. (2009). Predicting and changing behavior: The reasoned action approach. London, GBR: Psychology Press.

Goonan, K. J., Muzikowski, J. A., \& Stoltz, P. K. (2009). Journey to excellence: How baldridge health care leaders succeed. Milwaukee, WI: American Society for Quality, Quality Press. 
539 Griffith, C. J. (2010)a. "Do businesses get the food poisoning they deserve?" British Food 540 Journal 112(4): 416-425.

541 Griffith, C. J., et al. (2010)b. "The assessment of food safety culture." British Food Journal 542 112(4): 439-456.

543 Hinsz, V. B., Nickell, G. S., \& Park, E. S. (2007). The role of work habits in the motivation of 544 food safety behaviors. Journal of Experimental Psychology: Applied, 13(2), 105-114. $545 \quad$ doi:10.1037/1076-898X.13.2.105

546 Hofstede, Hofstede, and Minkov, (2010) p.47. "Cultures and Organizations: Software of the

International Diabetes Federation. (2014). Facts and figures. Retrieved from http://www.idf.org/worlddiabetesday/toolkit/gp/facts-figures

International Union of Food Science and Technology (IUFoST). (2015). Foodborne disease and vulnerable groups. (IUFoST Scientific Information Bulletin (SIB)). IUFoST. University of Guelph master's thesis.

554 Jespersen, L. and R. Huffman (2014). "Building food safety into the company culture: a look at Maple Leaf Foods." Perspectives in Public Health (May 8, 2014). 
Jespersen, L. et al (2016). "Measuring food safety culture using content analysis." Manuscript in preparation.

Lund, Barbara M., O’Brien, Sarah J. (2011). "The Occurrence and Prevention of Foodborne Disease in Vulnerable People" Foodborne Pathog Dis. 2011 Sep; 8(9): 961-973.

Nickell, G. S., \& Hinsz, V. B. (2011). Having a conscientious personality helps an organizational climate of food safety predict food safety behaviour. Food Supplies and Food Safety, pp. 189-198.

Powell, D. A., et al. (2011). "Enhancing food safety culture to reduce rates of foodborne illness."

Food Control 22(6): 817-822.

Rohr, A., Luddecke, K., Drusch, S., Muller, M.J., Alvensleben, R.v. (2005). "Food quality and safety—consumer perception and public health concern." Food Control 16: 649-655.

Schein, E. H. (2004). Organizational culture and leadership. San Francisco: San Francisco : Jossey-Bass.

Taylor, J. (2011). "An exploration of food safety culture in a multi-cultural environment: next steps?" Worldwide Hospitality and Tourism Themes 3(5): 455-466.

Taylor J., Jean Pierre Garat Samer Simreen Ghida Sarieddine , (2015),"An industry perspective", Worldwide Hospitality and Tourism Themes, Vol. 7 Iss 1 pp. 78 - 89 $\square$ 
574 United Nations, Department of Economic and Social Affairs. (2012). World population prospects.

575 The 2012 revision. Retrieved from

576 http://esa.un.org/wpp/Documentation/pdf/WPP2012 Volume-I Comprehensive-Tables.pdf

577 Yiannas, F. (2009). Food safety culture creating a behavior-based food safety management

578 system, New York : Springer, c2009.

579 Yiannas, F. (2015). Food Safety = Behavior: 30 Proven Techniques to Enhance Employee

580 Compliance, Springer.

581 WHO FERG website: http://www.who.int/mediacentre/news/releases/2015/food-safety/en/

582 United Nations, Department of Economic and Social Affairs, 2012

583 Wright, M. "A tool to diagnose culture in food business operators, Food Standards Agency

584 Research Report, 2013." http://www.foodbase.org.uk//admintools/reportdocuments/803-1-1430_

585 FS245020.pdf www.food.gov.uk, accessed April 3, 2014. 
Table 1: Population subgroup and relative susceptibility adapted from WHO and FAO (2009), PHAC (2010, and CDC data (2010).

\section{Population Sub-Group}

Relative Susceptibility

Health members of population $<60$ years old

1.0

$>60$ years old

$>65$ years old

75-79 years old

9.0

Alcoholism

18.0

Pregnant woman

Diabetes - type 2

25.0

Diabetes - type 1

30.0

Aids and HIV

865.0

Organ transplant recipients

$2,584.0$

Table 2: Cultural dimensions and components of organizations adapted from Schein, 2004 (Jespersen et al, 2015)

\begin{tabular}{ll}
\hline \multicolumn{1}{c}{ Dimension } & Components \\
\hline External adaptation & Mission and goals, means (e.g., day-to-day behaviours, skills, \\
knowledge, time and technology) to reach goals, degree of \\
autonomy, how does the organization decide what to measure,
\end{tabular}




\section{Dimension}

Components

measures (what and how), how to judge success, remediate and repair processes, and crisis history.

Internal integration

Reality and truth

Time and space

Human nature, activity and relationship
System of communication, common language, group selection and exclusion criteria, allocation systems (e.g., influence, power and authority), rules for relationships and systems for rewards and punishment.

High vs. low context, definition of truth, information, data, and knowledge needs; training and competencies; systems (e.g., sign-off), continuous improvement.

Four different dimensions for characterizing time orientation; assumptions around time management.

Theory $\mathrm{x} / \mathrm{y}$ managers, the doing/being/being-in-becoming orientation, and four basic problems solved in a group: identity and role; power and influence; needs and goals; acceptance and intimacy, individualism/groupism, power distance and accepted behaviours \& practices. 
Table 3: Structure and rigour of maturity models applied to other disciplines

\begin{tabular}{llc}
\hline Maturity Model (Name) & Stages/Levels & $\begin{array}{c}\text { Results from } \\
\text { application }\end{array}$ \\
\hline Quality management & Five stages; Uncertainty, Awakening, & No \\
(Quality Management & Enlightenment, Wisdom, and Certainty \\
Grid) & \\
Health care (Baldridge) & Five stages; Reaction, Projects, \\
& Traction, Integration, and Sustaining \\
& & Six levels; Non-existent, Initial/ad hoc, \\
Information technology & Repeatable but Intuitive, Defined \\
(CobiT) & Process, Managed and Measurable, and \\
& Optimized
\end{tabular}

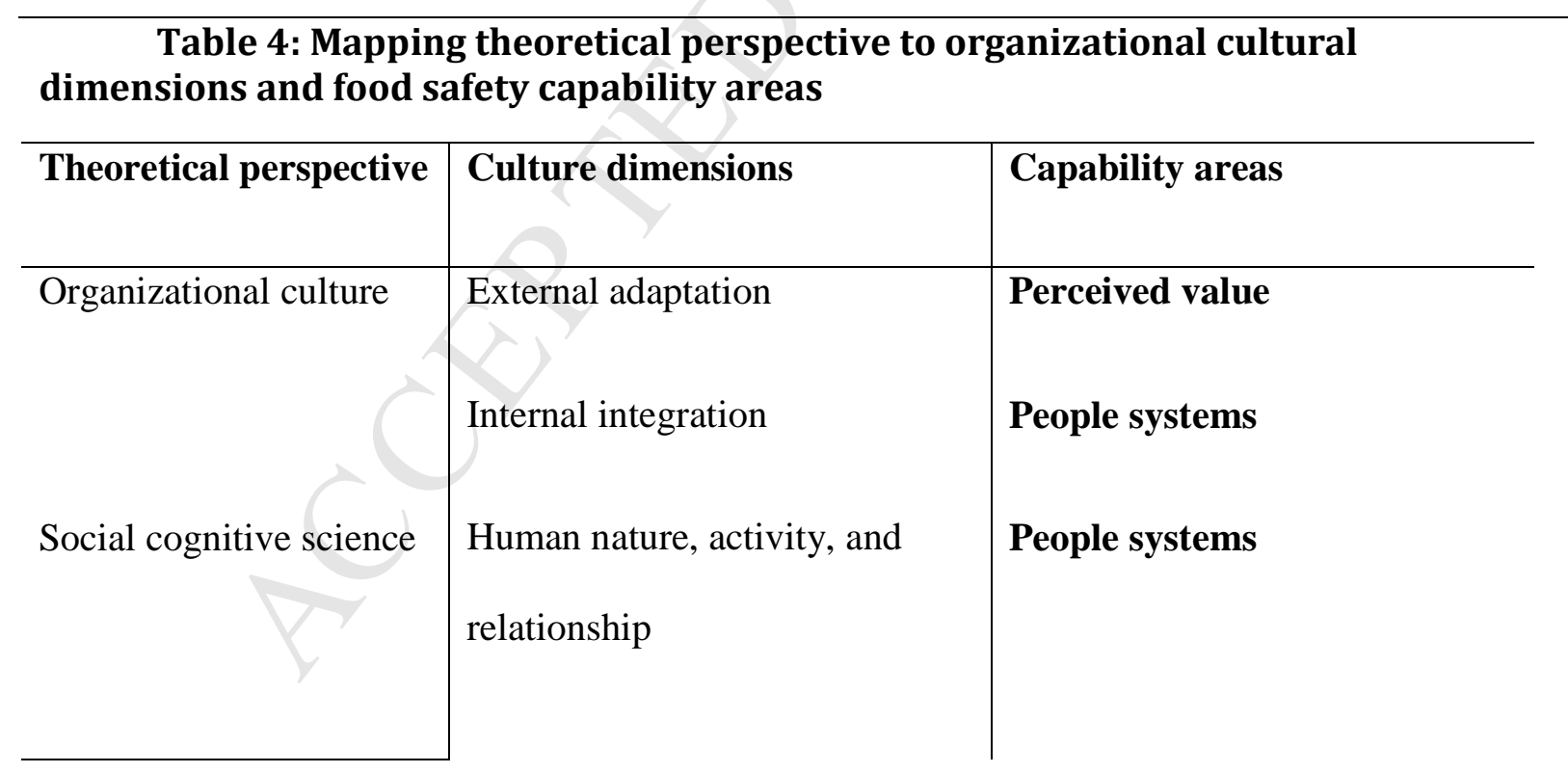




\begin{tabular}{l|l|l}
\hline Theoretical perspective & Culture dimensions & Capability areas \\
\hline & $\begin{array}{l}\text { Human nature, activity, and } \\
\text { relationship }\end{array}$ & Process thinking \\
Food science & Reality and truth & Technology enabled \\
& Reality and truth & Tools and infrastructure \\
\hline
\end{tabular}

Table 5: Variable and statement format for describing pinpointed behaviours

\begin{tabular}{|c|c|c|}
\hline Variable & Standard start & Example pinpointed behaviour \\
\hline Attitude & My behaviour to . & $\begin{array}{l}\text {...always design my own tools e.g. } \\
\text { spreadsheet to gather food safety } \\
\text { data... }\end{array}$ \\
\hline Perceived & that for the & ....always design my own tools e.g. \\
\hline Control & next three months I will & $\begin{array}{l}\text { spreadsheet to gather food safety } \\
\text { data }\end{array}$ \\
\hline Social Norm & $\begin{array}{l}\text { Most people, outside -and } \\
\text { at work, whose opinion I } \\
\text { value would approve of ... }\end{array}$ & $\begin{array}{l}\text {...always design my own tools e.g. } \\
\text { spreadsheet to gather food safety } \\
\text { data }\end{array}$ \\
\hline Past Behaviour & $\begin{array}{l}\text { I have in the past three } \\
\text { months ... }\end{array}$ & $\begin{array}{l}\text {...always design my own tools e.g. } \\
\text { spreadsheet to gather food safety } \\
\text { data }\end{array}$ \\
\hline
\end{tabular}


Behavioural $\quad$ I intend to ...

Intent

data ...always design my own tools e.g.

spreadsheet to gather food safety

Page 5 of 13 
Table 6: Food Safety Maturity Model

\begin{tabular}{|c|c|c|c|c|c|}
\hline & \multicolumn{5}{|c|}{ Stage name } \\
\hline Capability Area & $\begin{array}{l}\text { Stage } 1 \\
\text { Doubt }\end{array}$ & $\begin{array}{l}\text { Stage } 2 \\
\text { React to }\end{array}$ & $\begin{array}{l}\text { Stage } 3 \\
\text { Know of }\end{array}$ & $\begin{array}{l}\text { Stage } 4 \\
\text { Predict }\end{array}$ & $\begin{array}{l}\text { Stage } 5 \\
\text { Internalize }\end{array}$ \\
\hline Perceived Value & $\begin{array}{l}\text { Completing tasks } \\
\text { because regulators make } \\
\text { us do so. } \\
\text { Food safety performance } \\
\text { data is not collected and } \\
\text { reported regularly to all } \\
\text { stakeholders. }\end{array}$ & $\begin{array}{l}\text { Little to no investment in } \\
\text { systems (people and } \\
\text { processes) to prevent food } \\
\text { safety firefighting. } \\
\text { Little understanding of true } \\
\text { food safety performance. }\end{array}$ & $\begin{array}{l}\text { Food safety issues are } \\
\text { solved one at a time, } \\
\text { getting to the root of the } \\
\text { issue, to protect the } \\
\text { business. } \\
\text { Strong, databased } \\
\text { understanding of true } \\
\text { food safety performance. }\end{array}$ & $\begin{array}{l}\text { Reoccurrence of food } \\
\text { safety issues is prevented } \\
\text { by used of knowledge and } \\
\text { leading indicators. }\end{array}$ & $\begin{array}{l}\text { Ongoing business } \\
\text { improvement and growth } \\
\text { is enabled by food safety. }\end{array}$ \\
\hline
\end{tabular}




\begin{tabular}{|c|c|c|c|c|c|}
\hline People System & $\begin{array}{l}\text { Tasks are only } \\
\text { completed when senior } \\
\text { leader's demand, } \\
\text { without understanding } \\
\text { responsibility, the task, } \\
\text { or why it is important. } \\
\text { Tasks being completed } \\
\text { out of fear for negative } \\
\text { consequences. } \\
\text { Top management having } \\
\text { to individually certify } \\
\text { the accuracy of food } \\
\text { safety information. }\end{array}$ & $\begin{array}{l}\text { Responsibilities for } \\
\text { problems are established as } \\
\text { the problems are } \\
\text { discovered and solved } \\
\text { mostly by use of negative } \\
\text { consequences. } \\
\text { Tools are invented as new } \\
\text { problems arise and the tools } \\
\text { are rarely incorporated into } \\
\text { systems for future use. }\end{array}$ & $\begin{array}{l}\text { Deeper understanding for } \\
\text { the importance of foods } \\
\text { safety systems, where } \\
\text { responsibilities are } \\
\text { clearly defined and } \\
\text { communicated, is gained } \\
\text { one issue at a time. } \\
\text { Consequences are mostly } \\
\text { managed when mistakes } \\
\text { happen, seldom through a } \\
\text { defined plan, with both } \\
\text { positive and negative } \\
\text { consequences. }\end{array}$ & $\begin{array}{l}\text { Develop and assess tools } \\
\text { for improving processes } \\
\text { through knowledge and } \\
\text { data. } \\
\text { Responsibilities and } \\
\text { accountabilities are } \\
\text { discussed, communicated, } \\
\text { and assessed with } \\
\text { patience. } \\
\text { Processes are developed, } \\
\text { including consequences } \\
\text { (positive and negative), } \\
\text { and managed preventive } \\
\text { through communication } \\
\text { and assessment. }\end{array}$ & $\begin{array}{l}\text { Strategic direction is set } \\
\text { across the complete } \\
\text { organization with } \\
\text { defined accountabilities, } \\
\text { responsibilities, and food } \\
\text { safety as one of the } \\
\text { business enablers. } \\
\text { Preventive definition and } \\
\text { continuous improvement } \\
\text { of specific food safety } \\
\text { behaviours, } \\
\text { consequences and tools. }\end{array}$ \\
\hline
\end{tabular}

Page 7 of 13 


\begin{tabular}{|c|c|c|c|c|c|}
\hline Process Thinking & $\begin{array}{l}\text { Unstructured problem } \\
\text { solving to remove the } \\
\text { immediate pain. }\end{array}$ & $\begin{array}{l}\text { "Plan, Do, Check, Act" } \\
\text { with emphasis on control in } \\
\text { the check phase and } \\
\text { expectation of an } \\
\text { immediate } 100 \% \text { perfect } \\
\text { solution. }\end{array}$ & $\begin{array}{l}\text { Structure problem solving } \\
\text { with significant risk of } \\
\text { over analyzing. }\end{array}$ & $\begin{array}{l}\text { "Plan, Do, Study, Act" } \\
\text { with emphasis on study } \\
\text { and not control. Problem } \\
\text { solving is accepted as an } \\
\text { iterative process. }\end{array}$ & $\begin{array}{l}\text { Horizon scanning and } \\
\text { continuous improvement } \\
\text { are used to identify risks. } \\
\text { Risks inform the } \\
\text { development and/or } \\
\text { improvement of } \\
\text { mitigation plans. } \\
\text { Mitigation plans are } \\
\text { integrated in the global } \\
\text { business management } \\
\text { system. }\end{array}$ \\
\hline
\end{tabular}




\begin{tabular}{|c|c|c|c|c|c|}
\hline $\begin{array}{l}\text { Technology } \\
\text { Enabled }\end{array}$ & $\begin{array}{l}\text { Little technology being } \\
\text { adopted and few see this } \\
\text { to be an issue. }\end{array}$ & $\begin{array}{l}\text { Responsibility is left to the } \\
\text { individual to identify data } \\
\text { needed and there is a high } \\
\text { reliance on the individual to } \\
\text { derive information from the } \\
\text { data. }\end{array}$ & $\begin{array}{l}\text { Standard technology is } \\
\text { adopted on going and } \\
\text { standardized training } \\
\text { provided to individuals as } \\
\text { needed. } \\
\text { It is unlikely to see that } \\
\text { issues are prevented by } \\
\text { use of data-driven } \\
\text { information. }\end{array}$ & $\begin{array}{l}\text { Data is collected in a } \\
\text { precise and accurate } \\
\text { manner to constantly } \\
\text { improve processes. } \\
\text { Automation is used in a } \\
\text { limited or fragmented } \\
\text { way. }\end{array}$ & $\begin{array}{l}\text { Integrated, global } \\
\text { information systems } \\
\text { (e.g., ERP) are in place } \\
\text { in the organization } \\
\text { making it quick to adapt, } \\
\text { improve, and use } \\
\text { automated workflows. }\end{array}$ \\
\hline $\begin{array}{l}\text { Tools and } \\
\text { Infrastructure }\end{array}$ & $\begin{array}{l}\text { Minimal tools in the } \\
\text { hands of few } \\
\text { individuals. }\end{array}$ & $\begin{array}{l}\text { It takes a problem to get the } \\
\text { right tools. This often leads } \\
\text { to findings the right tools in } \\
\text { a hurry and resulting in } \\
\text { rework. }\end{array}$ & $\begin{array}{l}\text { The organization invests } \\
\text { readily in the right tools } \\
\text { and infrastructure when } \\
\text { solving a problem calls } \\
\text { for it. }\end{array}$ & $\begin{array}{l}\text { Food safety tools and } \\
\text { infrastructures are in place } \\
\text { and are continuously } \\
\text { improved for ease of use } \\
\text { and cost of the } \\
\text { organization. }\end{array}$ & $\begin{array}{l}\text { Investment in tools and } \\
\text { infrastructure is } \\
\text { evaluated long-term and } \\
\text { prioritized along with } \\
\text { other business } \\
\text { investments. }\end{array}$ \\
\hline
\end{tabular}


MEASURING FOOD SAFETY CULTURE IN FOOD MANUFACTURING.

Table 7: Sample pinpointed behaviours by function (food safety and quality), 5 role and competency areas in the maturity stages of doubt and internalized

\begin{tabular}{|c|c|c|c|c|}
\hline Capability area & $\begin{array}{l}\text { Supervisor } \\
\text { (Execute) }\end{array}$ & $\begin{array}{l}\text { Leader } \\
\text { (Tactic) }\end{array}$ & $\begin{array}{l}\text { Functional Leader } \\
\text { (Strategy) }\end{array}$ & Executive (Vision) \\
\hline $\begin{array}{l}\text { People System } \\
\text { (DOUBT) }\end{array}$ & $\begin{array}{l}\text { I immediately } \\
\text { remove food safety } \\
\text { issues by myself to } \\
\text { avoid negative } \\
\text { consequences for my } \\
\text { team and myself. }\end{array}$ & $\begin{array}{l}\text { I provide my direct } \\
\text { reports with } \\
\text { direction to remove } \\
\text { food safety problems } \\
\text { immediately to avoid } \\
\text { negative } \\
\text { consequences. }\end{array}$ & $\begin{array}{l}\text { I always have to } \\
\text { manage negative } \\
\text { consequences when } \\
\text { a food safety } \\
\text { problem occurs. }\end{array}$ & $\begin{array}{l}\text { I make sure } \\
\text { somebody is } \\
\text { managing negative } \\
\text { consequences every } \\
\text { time a food safety } \\
\text { problem occurs. }\end{array}$ \\
\hline $\begin{array}{l}\text { People System } \\
\text { (INTERNALIZED) }\end{array}$ & $\begin{array}{l}\text { I take action daily to } \\
\text { let anybody know } \\
\text { when they go over } \\
\text { and beyond for food } \\
\text { safety. }\end{array}$ & $\begin{array}{l}\text { I take action daily to } \\
\text { provide positive } \\
\text { feedback when } \\
\text { others take action to } \\
\text { remove perceived } \\
\text { food safety risks. }\end{array}$ & $\begin{array}{l}\text { I take action daily to } \\
\text { complement my } \\
\text { peers in other } \\
\text { functions of their } \\
\text { demonstrated food } \\
\text { safety ownership. }\end{array}$ & $\begin{array}{l}\text { I minimum monthly } \\
\text { check in with } \\
\text { functional - and } \\
\text { business leaders to } \\
\text { ensure food safety is } \\
\text { built into their } \\
\text { business plans. }\end{array}$ \\
\hline
\end{tabular}


Figure 1: Overall company behaviour-based maturity



Page 11 of 13 


\section{Capability Area}

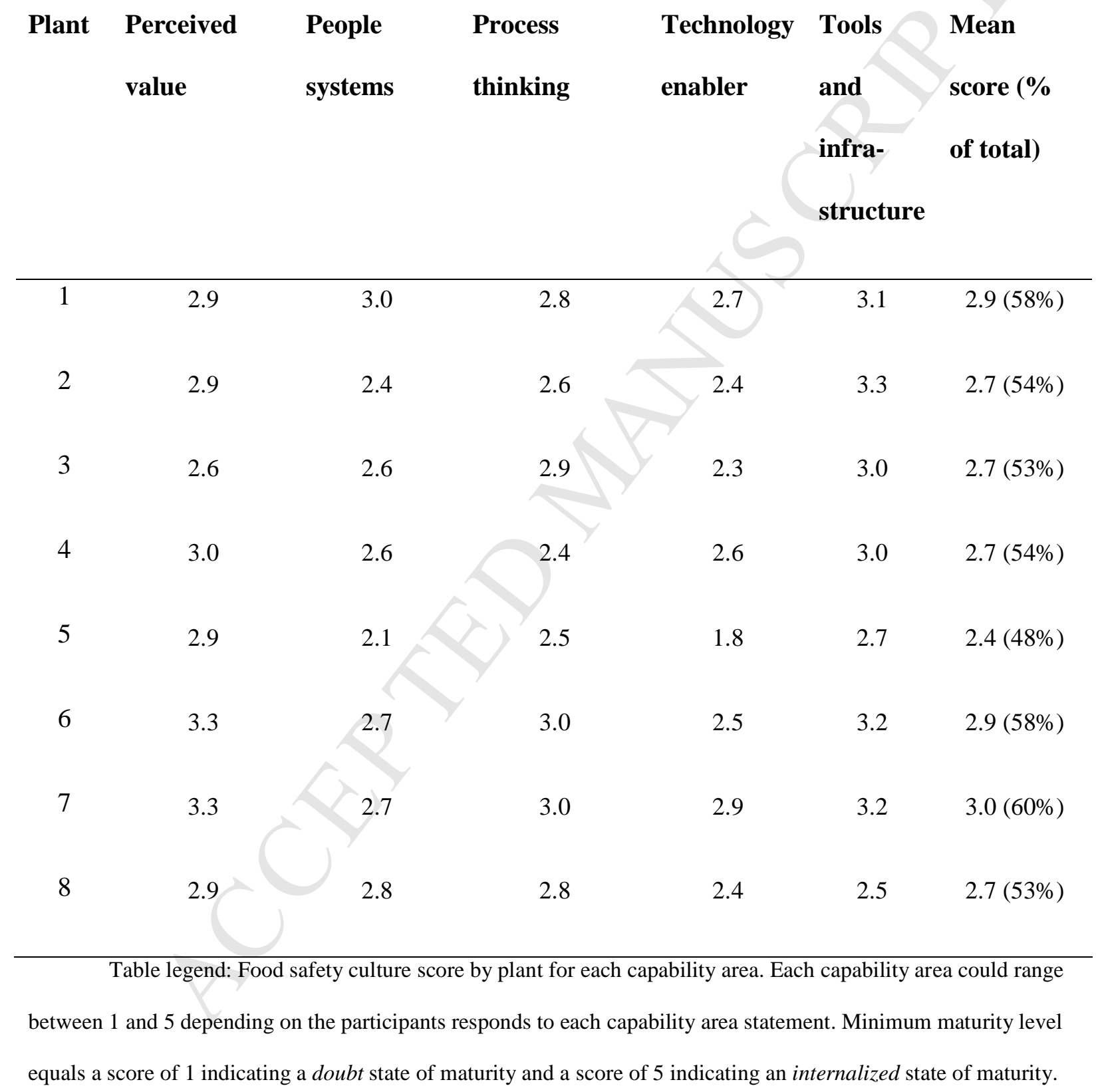


14 Average for each plant was calculated and a percentage achieved calculated to quantify strength of each plants food 15 safety culture. 